\title{
Nitric oxide inhibits the transcription of E6 gene of human papillomavirus
}

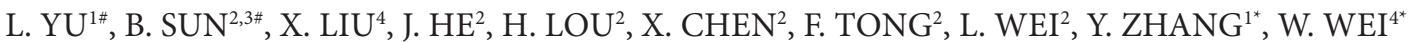

\begin{abstract}
${ }^{1}$ Department of Gynecology, the Third Affiliated Tumor Hospital of Harbin Medical University, Heilongjiang, P. R. China; ${ }^{2}$ Department of Microbiology, Harbin Medical University, Heilongjiang, P. R. China; ${ }^{3}$ Biomedical Translational Research Institute, International Immunology Center, Jinan University, Guangzhou, P. R. China; ${ }^{4}$ Department of Surgery, the first Affiliated Hospital of Jiamusi University, 348 Dexiang Road, Jiamusi 154007, P. R. China
\end{abstract}

Received June 05, 2017; revised March 29, 2018; accepted October 3, 2018

\begin{abstract}
Summary. - High-risk human papillomavirus (HPV) is an important pathogenic factor for cervical cancer and understanding the mechanism of HPV gene transcription is important for the prevention and therapy of HPV related cervical cancer. This study aimed to investigate the role of nitric oxide (NO) in the regulation of HPV gene transcription. SiHa cells containing integrated HPV16 were treated with NO donor DETA-NO and cell proliferation and cytotoxicity were determined. HPV gene transcription was detected by real-time PCR. We found no significant cytotoxic effects on SiHa cells when the concentration of DETA-NO was less than 0.5 $\mathrm{mmol} / \mathrm{l}$. The transcription of HPV E6 gene was inhibited by DETA-NO in a dose-dependent manner and the best inhibitory effect was observed at $0.5 \mathrm{mmol} / \mathrm{l}$ DETA-NO. In addition, ERK inhibitor U0126 decreased the transcription of HPV E6 gene at the concentration of $30 \mu \mathrm{mol} / \mathrm{l}$. In conclusion, NO inhibits the transcription of HPV E6 gene and probably involves MAPK signaling pathway.
\end{abstract}

Keywords: SiHa cells; nitric oxide; MAPK pathway; HPV transcription

\section{Introduction}

Cervical cancer is one of the most common cancers of women worldwide. China is a high incidence area of cervical cancer, with an annual increase of over 46,000 cases, and the death toll is 26,000 . Infection of high-risk human papillomavirus (HPV) is one of the important factors of cervical cancer. HPV is a group of small, non-enveloped, double-stranded DNA viruses and exists in episomal and integrative forms in cervical cancer cells. E6 and E7 are oncogenes which induce and maintain phenotypic transformation of HPV. HPV E6 and E7 proteins interact with

*Corresponding authors. E-mail: wei720605@126.com, phone: +8613945485872 (Wei Wei); zhangyunyan_1972@163.com, phone: +8645182576777 (Yunyan Zhang). "Equal contribution: Libo Yu \& Bowen Sun.

Abbreviations: DETA-NO = (Z)-1-[2-(2-aminoethyl) $-\mathrm{N}-(2-$ ammonioethyl) amino] diazen-1-ium-1,2-diolate; ERK = extracellular signal-regulated kinase; HPV = human papillomavirus; JNK = Jun $\mathrm{N}$-terminal kinase; $\mathrm{MAPK}=$ mitogen-activated protein kinase; $\mathrm{NO}=$ nitric oxid p53 and $\mathrm{Rb}$ respectively, contributing to the progression of cervical cancer. E6 initiates the degradation of tumor suppressor protein $\mathrm{p} 53$, while E7 promotes $\mathrm{G}_{1} / \mathrm{S}$ transition of cell cycle by binding to Rb. Changes in E6 and E7 levels will affect cervical cancer development and metastasis and the efficacy of chemotherapy for cervical cancer.

Nitric oxide (NO) is an endogenous gas with short half-life and has been regarded as an important signal molecule. NO is synthesized by a complex family of nitric oxide synthase (NOS), including neuronal NOS (nNOS), endothelial NOS (eNOS) and inducible NOS (iNOS), which induces the synthesis of high concentrations of NO (Moncada and Higgs 1993). Recent studies have demonstrated that high levels of NO modulate gene expression through the formation of S-nitroso (SNO) bonds in multiple transcriptional activators (Nott and Riccio, 2009). However, the effects of high concentrations of NO on the integrated HPV in cervical cancer cells remain unknown.

A variety of cancer-related biological processes, including angiogenesis, apoptosis, cell cycle, invasion and metastasis, are regulated by mitogen-activated protein kinase (MAPK) 
signaling pathway. It was shown that increased ERK1 expression was associated with high-risk HPV infection (Branca et al., 2004). Yuan et al. (2009) found that E7 regulated cadherin-mediated cell adhesion through the modulation of cadherin expression via extracellular signal-regulated kinase (ERK) signaling pathway. In addition, Yu et al. (2007) demonstrated that efficient nuclear import of HPV11 E1 protein depended on the phosphorylation of the serine residues S89 and S93 by MAPK pathway. Interestingly, Baek et al. (2015) found that NO induced the apoptosis of human gingival fibroblasts via the regulation of Bcl-2 family and Jun N-terminal kinase (JNK) activation. Notably, NO regulated the proliferation of HPV-infected cells via ERK and MAPK signaling pathways (Park, 2013). Therefore, we hypothesize that high concentration of NO may affect HPV E6 transcription through MAPK signaling pathway.

In this study, SiHa cell line, a cervical cancer cell line with integrated HPV 16, was chosen as a model to investigate the effect of NO on the transcription of HPV E6 gene. Meanwhile, ERK inhibitor, p38 inhibitor and JNK inhibitor were employed to examine the role of MAPK signaling in mediating the effect of NO on HPV E6 gene transcription.

\section{Materials and Methods}

Reagents. Dulbecco's modified Eagle's medium (DMEM) and fetal bovine serum (FBS) were purchased from HyClone Laboratories of Thermo Scientific (USA). NO donor (Z)-1-[2-(2-aminoethyl)$\mathrm{N}$-(2- ammonioethyl) amino] diazen-1-ium-1, 2-diolate (DETANO) was purchased from Cayman (USA). ERK1/2-MAPK inhibitor (U0126) was purchased from Sigma-Aldrich (USA), p38-MAPK inhibitor (SB203580) and JNK-MAPK inhibitor (SP600125) were purchased from MERCK (Germany). The primers, Taq polymerase, dNTP, Rnasin and diethyl pyrocarbonate (DEPC) were provided by TaKaRa Bio Inc. (Japan). Primary antibodies for extracellular signal-regulated kinase 1/2 (ERK1/2), phospho-(Thr202/Tyr204) p42/p44, p38 mitogen-activated protein kinase (MAPK), phospho-(Thr180/Tyr182) p38, stress-activated protein kinase/Jun N-terminal kinase (SAPK/JNK) and phospho-(Thr183/Tyr185), SAPK/JNK were purchased from Cell Signaling Technology (USA). The antibody for GAPDH and horseradish peroxidase conjugated secondary antibodies were purchased from ZSGB-BIO (China).

Cell culture and treatment. The human cervical carcinoma cell line $\mathrm{SiHa}$ (HPV16-positive) was provided by Department of Microbiology, Harbin Medical University, Heilongjiang Provincial Key Laboratory for Infection and Immunity. SiHa cells were cultured in DMEM supplemented with 5\% FBS and $100 \mathrm{U} / \mathrm{ml}$ penicillin at $37^{\circ} \mathrm{C}$ with $5 \% \mathrm{CO}_{2}$ atmosphere. The cells were routinely passaged, at 2-3-day intervals. SiHa cells were exposed to DETA-NO ( $0 \mathrm{mmol} / \mathrm{l}, 0.0625 \mathrm{mmol} / \mathrm{l}, 0.125 \mathrm{mmol} / \mathrm{l}, 0.25 \mathrm{mmol} / \mathrm{l}, 0.5 \mathrm{mmol} / \mathrm{l}$ and $1 \mathrm{mmol} / \mathrm{l}$ ), and the Trypan blue exclusion staining was used to assess the cell numbers after DETA-NO treatment for $0 \mathrm{~h}, 1 \mathrm{~h}$,
$24 \mathrm{~h}, 48 \mathrm{~h}$ and $72 \mathrm{~h}$. Cytoxicity was measured based on the assay of lactate dehydrogenase (LDH) in cell-free supernatants. In addition, cells were treated with $\mathrm{U} 0126(0 \mu \mathrm{mol} / \mathrm{l}, 20 \mu \mathrm{mol} / \mathrm{l}$ and $30 \mu \mathrm{mol} / \mathrm{l})$, SB203580 $(0 \mu \mathrm{mol} / \mathrm{l}, 5 \mu \mathrm{mol} / \mathrm{l}$ and $10 \mu \mathrm{mol} / \mathrm{l})$, or SP600125 $(0 \mu \mathrm{mol} / \mathrm{l}$, $10 \mu \mathrm{mol} / \mathrm{l}$ and $20 \mu \mathrm{mol} / \mathrm{l})$ alone or together with DETA-NO.

Quantitative real-time PCR. Total RNA was extracted using TRIzol reagent (Invitrogen, USA). The first strand cDNAs were synthesized using PrimeScript RT reagent kit (TaKaRa) following the manufacturer's instructions. Quantitative real-time polymerase chain reaction (qRT-PCR) was performed in triplicate in a LightCycler2.0 (Roche Diagnostics) and normalized to glyceraldehyde 3-phosphatedehydrogenase (GAPDH) as internal control. The data were analyzed using the $2^{-\triangle \triangle \mathrm{Ct}}$ method. HPV16 E6 primer sequences were: 5'-GAACAGCAATACAACAA-ACCG-3' (sense) and 5'-CGCTTCACGAATTTGCGTGTCAT-3' (antisense); GAPDH primer sequences were: 5'-GAAGGTGAAGGTCGGAGTC-3' (sense) and 5'-GAAGATGGTGATGG-GATTTC-3' (antisense).

Western blot analysis. Western blot analysis was performed using routine protocols. Primary antibodies included ERK1/2 (1:1000), phospho-ERK1/2 (1:500), p38 (1:1000), phospho-p38 (1:1000), JNK (1:1000) and phospho-JNK (1:1000). GAPDH was used as loading control. Protein bands were detected using an enhanced chemiluminescence (ECL) reagent (Bio-Rad, China). The images were quantified by LAS-4000 (FUJIFILM, Japan).

Statistical analysis. Values were expressed as means \pm SEM. Statistical analysis was performed with Student's $t$ test for paired data or ANOVA followed by Fischer's test. Values of $\mathrm{P}<0.05$ were considered as statistically significant.

\section{Results}

\section{NO inhibits the proliferation of SiHa cells}

To test the effect of different concentrations of DETA$\mathrm{NO}$ on the proliferation of $\mathrm{SiHa}$ cells, $\mathrm{SiHa}$ cells were

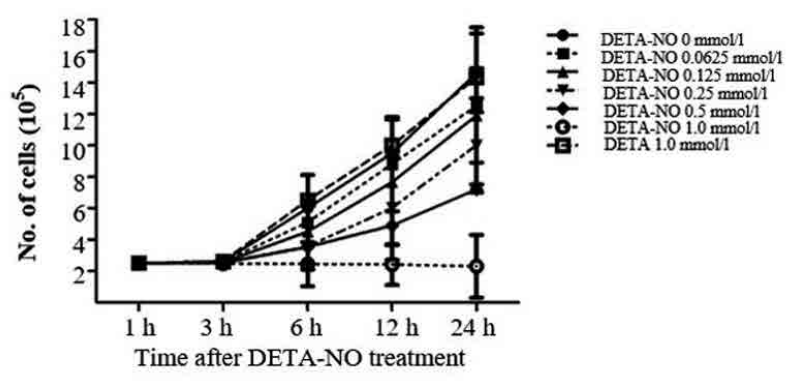

Fig. 1

NO inhibits SiHa cell viability

$\mathrm{SiHa}$ cells were treated with different concentrations of DETA-NO ( $0 \mathrm{mmol} / \mathrm{l}, 0.0625 \mathrm{mmol} / \mathrm{l}, 0.125 \mathrm{mmol} / \mathrm{l}, 0.25 \mathrm{mmol} / \mathrm{l}, 0.5 \mathrm{mmol} / \mathrm{l}$ and $1 \mathrm{mmol} / \mathrm{l}$ ) for indicated time. The viability was calculated as the percentage of viable cells in treated cultures compared to those in control cultures. Data were expressed as mean $\pm S D(n=3)$. 

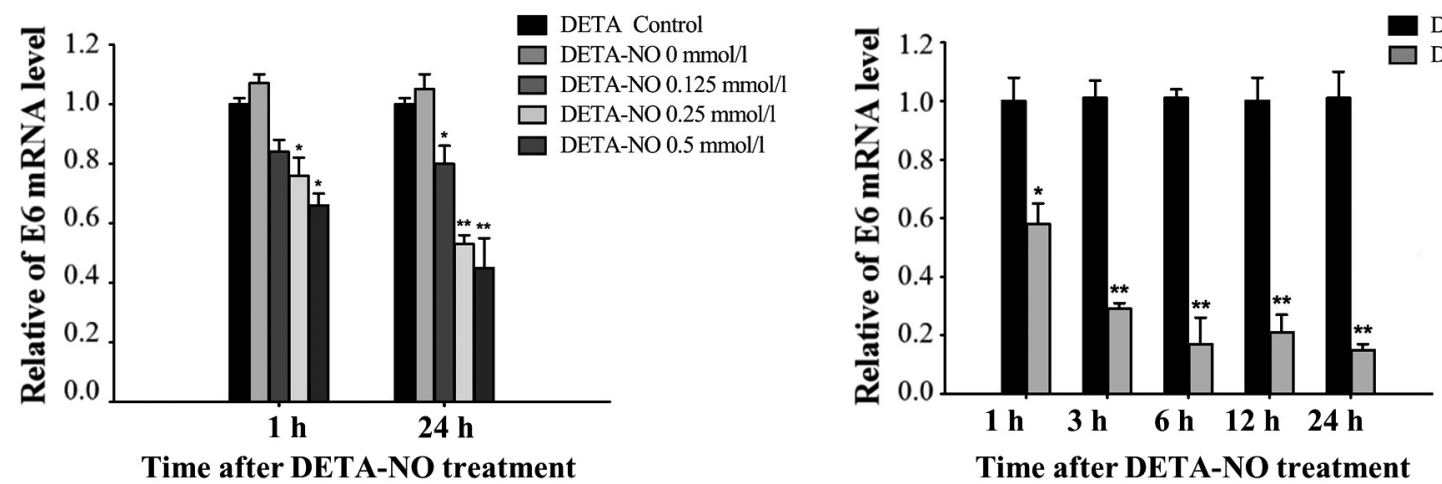

Fig. 2

NO inhibits HPV E6 mRNA expression in SiHa cells

$\mathrm{SiHa}$ cells were treated with different concentrations of DETA-NO $(0 \mathrm{mmol}, 0.125 \mathrm{mmol} / \mathrm{l}, 0.25 \mathrm{mmol} / \mathrm{l}$ and $0.5 \mathrm{mmol} / \mathrm{l})$ for $1 \mathrm{~h}$ and $24 \mathrm{~h}$ (a) or $0.5 \mathrm{mmol} / \mathrm{l}$ DETA-NO for different time (from $0.5 \mathrm{~h}$ to $24 \mathrm{~h}$ ) (b) The level of E6 mRNA was determined using real-time PCR analysis. Data were expressed as mean $\pm \mathrm{SD}(\mathrm{n}=3)$. ${ }^{*} \mathrm{P}<0.05,{ }^{* *} \mathrm{P}<0.01$ versus control.

(a)

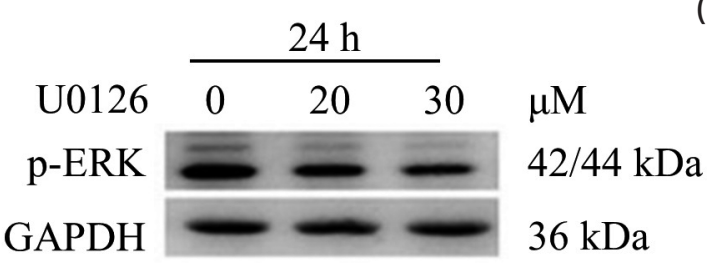

(c)

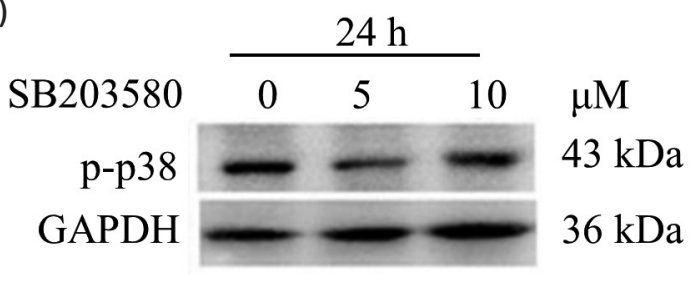

(e)

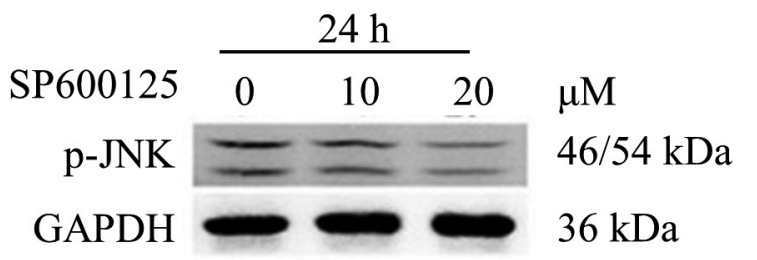

(b)

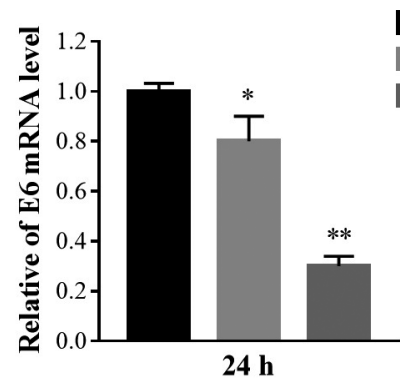

(d)

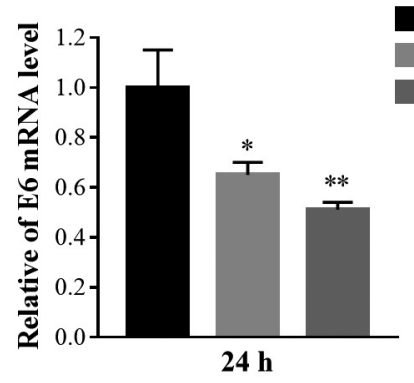

$\mathrm{SB} 2035800 \mathrm{mmol} / \mathrm{l}$ SB203580 $5 \mathrm{mmol} / 1$ SB203580 $10 \mathrm{mmol} / \mathrm{l}$

$\mathrm{U} 01260 \mathrm{mmol} / \mathrm{l}$ $\mathrm{U} 012620 \mathrm{mmol} / \mathrm{l}$

$\mathrm{U} 012630 \mathrm{mmol} / \mathrm{l}$

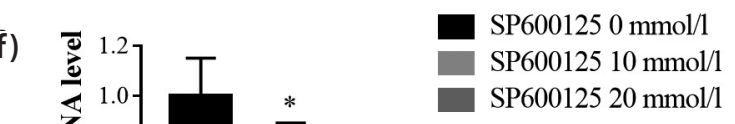

Fig. 3

MAPK inhibitors inhibit E6 mRNA expression in SiHa cells

$\mathrm{SiHa}$ cells were exposed to different concentrations of ERK inhibitor (U0126), p38 inhibitor (SB203580) and JNK inhibitor (SP600125) (0 $\mu$ mol/l, $5 \mu \mathrm{mol} / \mathrm{l}$ and $10 \mu \mathrm{mol} / \mathrm{l}$ ) for $24 \mathrm{~h}$. Western blot confirmed the inhibitory effects on ERK (a), p38 (c) and JNK (e). The level of E6 mRNA was determined using real-time PCR analysis in SiHa cells treated with U0126 (b), SB203580 (d) and SP600125 (f). Data were expressed as mean \pm SD $(n=3)$. ${ }^{*} \mathrm{P}<0.05$, ${ }^{* *} \mathrm{P}<0.01$ versus control. 
(a)

$\begin{array}{rllrll}\text { U0126 } & 0 & 0 & 30 & 30 & \mu \mathrm{M} \\ \text { EDTA-NO dose } & 0 & 0.5 & 0 & 0.5 & \mathrm{mM} \\ \text { p-ERK } & -\infty & -\infty & - & 42 / 44 \mathrm{kDa} \\ \text { GAPDH } & -\infty & 36 \mathrm{kDa}\end{array}$

(c)

\begin{tabular}{|c|c|c|c|c|}
\hline SB203580 & 0 & 0 & 30 & 30 \\
\hline EDTA-NO dose & 0 & 0.5 & 0 & 0.5 \\
\hline p-P38 & $=$ & - & - & - \\
\hline
\end{tabular}

(e)

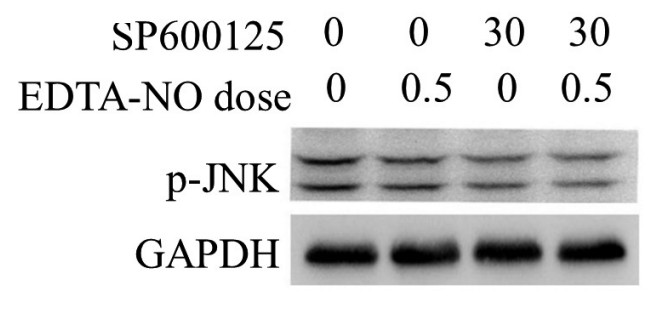

$\mu \mathrm{M}$

$\mathrm{mM}$

$46 / 54 \mathrm{kDa}$

$36 \mathrm{kDa}$ (b)

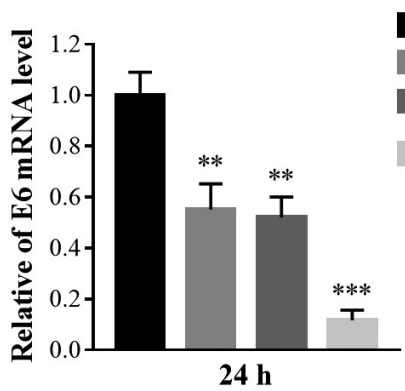

DETA-NO $0 \mathrm{mmol} / \mathrm{I}$ DETA-NO $0.5 \mathrm{mmol} / 1$ U0126 $30 \mu \mathrm{M}$ DETA-NO $0.5 \mathrm{mmol} / 1$ $+\mathrm{U} 012630 \mu \mathrm{M}$ (d)

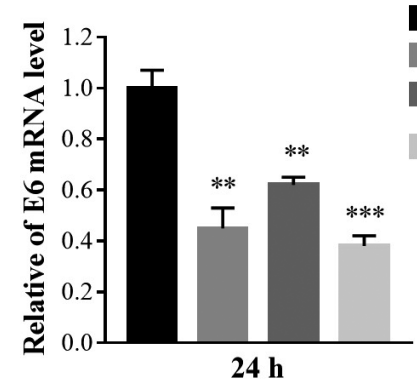

DETA-NO 0 mmol/ 1 DETA-NO $0.5 \mathrm{mmol} / \mathrm{l}$ SB203580 $5 \mu \mathrm{M}$ DETA-NO $0.5 \mathrm{mmol} / \mathrm{l}$ + SB203580 $5 \mu \mathrm{M}$ (f)

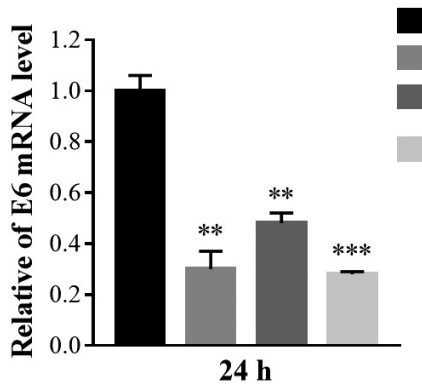

DETA-NO $0 \mathrm{mmol} / \mathrm{l}$

DETA-NO $0.5 \mathrm{mmol} / 1$ SP600125 $10 \mu \mathrm{M}$ DETA-NO $0.5 \mathrm{mmol} / 1$ + SP600125 $10 \mu \mathrm{M}$

Fig. 4

NO inhibits HPV E6 gene transcription in SiHa cells in synergy with ERK inhibitor

$\mathrm{SiHa}$ cells were treated with $0.5 \mathrm{mmol} / \mathrm{l}$ DETA, $0.5 \mathrm{mmol} / \mathrm{l}$ DETA-NO plus ERK inhibitor U0126 (30 $\mu \mathrm{mol} / \mathrm{l})$, p38 inhibitor SB203580 (10 $\mu \mathrm{mol} / \mathrm{l})$ and

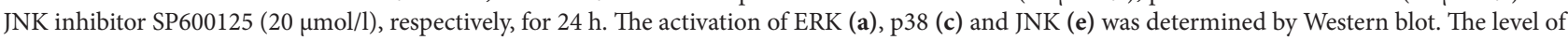
E6 mRNA was determined by real-time PCR in SiHa cells treated with DETA-NO plus U0126 (b), SB203580 (d) and SP600125 (f). Data were expressed as mean $\pm \mathrm{SD}(\mathrm{n}=3)$. ${ }^{\mathrm{P}} \mathrm{P}<0.05,{ }^{* *} \mathrm{P}<0.01$ versus control.

treated by different concentrations of DETA-NO $(0 \mathrm{mmol} / \mathrm{l}$, $0.0625 \mathrm{mmol} / 1,0.125 \mathrm{mmol} / 1,0.25 \mathrm{mmol} / \mathrm{l}, 0.5 \mathrm{mmol} / \mathrm{l}$ and $1 \mathrm{mmol} / \mathrm{l})$ for $1 \mathrm{~h}, 24 \mathrm{~h}, 48 \mathrm{~h}$ and $72 \mathrm{~h}$. The results showed that DETA-NO inhibited SiHa cell proliferation in a dose and time dependent manner (Fig. 1). After exposure to $1 \mathrm{mmol} / \mathrm{l}$ DETA-NO for $72 \mathrm{~h}$, inhibitory effect was most obvious, and the number of live cells was only $45 \%$ of the total number of cells in control group. When treatment time was less than $72 \mathrm{~h}$ and the concentration of DETA was less than $0.5 \mathrm{mmol} / \mathrm{l}$, the number of living cells was more than $50 \%$ of the total number of cells in control group. Therefore, when DETA-NO concentration was less than $0.5 \mathrm{mmol} / \mathrm{l}$ and treatment time was less than $72 \mathrm{~h}$, it could inhibit the proliferation of $\mathrm{SiHa}$ cells without obvious cytotoxic effects. Thus, we used DETA-NO at the concentration less than 0.5 $\mathrm{mmol} / \mathrm{l}$ in following experiments.

\section{NO inhibits the transcription of HPV E6 mRNA in SiHa cells}

Next, we examined the effect of $\mathrm{NO}$ on the expression of HPV16 E6 gene in SiHa cells. SiHa cells were treated with different concentrations of DETA-NO (0 mmol/l, 0.125 $\mathrm{mmol} / \mathrm{l}, 0.25 \mathrm{mmol} / \mathrm{l}$ and $0.5 \mathrm{mmol} / \mathrm{l}$ ) for $1 \mathrm{~h}$ or $24 \mathrm{~h}$, and E6 gene expression was detected by real-time PCR. The results showed that after exposure to different concentrations of 
DETA-NO for $1 \mathrm{~h}$ or $24 \mathrm{~h}$, the expression level of HPV E6 mRNA was decreased in a dose dependent manner (Fig. 2a). In addition, $\mathrm{SiHa}$ cells were treated with $0.5 \mathrm{mmol} / \mathrm{l}$ DETANO for 1 h, 3 h, 6 h, $12 \mathrm{~h}$ and 24 h, respectively. The results showed that DETA-NO treatment led to decreased HPV E6 mRNA level in a time dependent manner (Fig. 2b). Taken together, these results indicate that the expression of HPV E6 mRNA is inhibited by NO.

\section{MAPK signaling inhibitor decreases the transcription of HPV E6 gene}

To explore the role of MAPK signaling pathway in HPV gene transcription, SiHa cells were treated with ERK inhibitor U0126 $(20 \mu \mathrm{mol} / \mathrm{l}$ and $30 \mu \mathrm{mol} / \mathrm{l}), \mathrm{p} 38$ inhibitor SB203580 (5 $\mu \mathrm{mol} / \mathrm{l}$ and $10 \mu \mathrm{mol} / \mathrm{l}$ ) or JNK inhibitor SP600125 $(10 \mu \mathrm{mol} / \mathrm{l}$ and $20 \mu \mathrm{mol} / \mathrm{l})$ for $24 \mathrm{~h}$. Western blot analysis showed that the levels of p-ERK, p-p38 and p-JNK were decreased after treatment with respective inhibitors. With the higher concentration of the inhibitors, inhibitory effects on the levels of p-ERK (Fig. 3a), p-p38 (Fig. 3c) and p-JNK (Fig. 3e) were more obvious.

Next, the expression of HPV E6 mRNA in SiHa cells treated by MAPK inhibitors was detected by real-time PCR. The results showed that the expression level of HPV E6 mRNA was decreased after treatment with ERK inhibitor (Fig. 3b), p38 inhibitor (Fig. 3d) and JNK inhibitor (Fig. 3f), respectively. These data suggest that three branches of MAPK signaling pathway are involved in the regulation of HPV gene transcription.

NO inhibits HPV E6 gene transcription in synergy with ERK inhibitor

To examine whether MAPK signaling pathway is involved in NO induced suppression of HPV E6 transcription, $\mathrm{SiHa}$ cells were treated with $0.5 \mathrm{mmol} / \mathrm{l}$ DETA-NO together with ERK inhibitor U0126 (30 $\mu \mathrm{mol} / \mathrm{l}), \mathrm{p} 38$ inhibitor SB203580 $(10 \mu \mathrm{mol} / \mathrm{l})$ or JNK inhibitor SP600125 $(20 \mu \mathrm{mol} / \mathrm{l})$, respectively, for $24 \mathrm{~h}$. Then the levels of p-ERK, p-p38 and p-JNK were detected by Western blot analysis and the expression of HPV E6 mRNA was detected by real time-PCR (Fig. 4). Compared with the control, after exposure to $0.5 \mathrm{mmol} / \mathrm{l}$ DETA-NO, the level of p-ERK increased, while the levels of p-p38 and p-JNK were unchanged. Moreover, DETA-NO combined with U0126 significantly inhibited the expression of HPV E6 mRNA, but SB203580 and SP600125 had no significant effects on the expression of HPV E6 mRNA. These data indicate that NO combined with ERK inhibitor further decrease HPV E6 mRNA expression.

\section{Discussion}

Most cervical cancers are caused by HPV, but not all types of HPV cause cervical cancer. Experimental and epidemiological evidences suggest that HPV infection is necessary but not sufficient to induce cancer. Other accessory factors such as NO are involved in the progression of infected cells to full neoplastic phenotype. NO can inhibit the replication of a variety of viruses, such as murine poxvirus and herpes viruses including HSV and Epstein-Barr virus (EBV), and RNA viruses including coxsackievirus (Yu et al., 2013; Gao, et al., 1999; Akaike and Maeda, 2000). In this study we found that in SiHa cells with integrated HPV, NO caused dose and time dependent inhibition of the expression of HPV early gene E6 mRNA, indicating that $\mathrm{NO}$ inhibits the replication of HPV.

NO participates in the activation of multiple pathways in various cells. NO inhibits STAT3 and AKT signaling pathway, inducing ovarian cancer cell apoptosis (Kielbik et al., 2013). NO induces the release of IL-6 to activate MAPK pathway in human renal epithelial cells (Demirel et al., 2012). Moreover, NO activates MAPK to regulate the occurrence and development of cervical cancer through affecting HPVinfected HeLa cell proliferation (Feng et al., 2013). MAPK is an important signaling pathway including three branches ERK, p38 and JNK protein. In physiological concentration (<30 nmol/l), NO activates ERK pathway through sGC (Miyamoto et al., 2011; Komatsu et al., 2009); at moderate concentration (50-300 nmol/l), NO activates ERK pathway through sGC and Ras pathway (Yasui et al., 2010; Gallo and Iadecola, 2011); at concentration $>500 \mathrm{nmol} / \mathrm{l}$, NO activates ERK pathway through the nitration of some proteins (Ridnour et al., 2006). Therefore, we hypothesized that high concentration of NO may inhibit E6 transcription through the regulation of MAPK signaling pathway. We found that when SiHa cells were treated with both DETA-NO and ERK inhibitor, E6 mRNA expression level decreased significantly. These findings suggest that ERK is involved in NO induced suppression of HPV E6 transcription.

NO synthesized by iNOS synthase is usually in a high level and persists for a long time. NO participates in tumor development to modulate different cancer-related events including angiogenesis, apoptosis, cell cycle, and invasion (Xu et al., 2002). NO has been reported to exert dichotomous effects in different cancers. On one hand, NO could have stimulatory efforts on tumor. For example, NO contributes to tumor angiogenesis by upregulating VEGF (Xu et al., 2002). On the other hand, NO has shown tumoricidal effects. NO exhibited cytostatic and/or cytotoxic effect on tumor cells by suppressing cellular respiration and DNA synthesis. NO also acts as a proapoptotic modulator to activate the caspase family proteases, modulate tumor DNA repair by upregulating p53, PARP and DNA-PKcs (Choudhari et al., 2013). 
Epidemiologic and experimental studies have confirmed a causal role of high-risk HPV in cervical carcinogenesis (Walboomers et al., 1999). Persistent viral infection in combination with constitutive expression of E6 and E7 viral oncogenes is necessary for malignant transformation, because these proteins can interact with p53 and pRB, leading to their degradation and cell cycle deregulation (Boyer et al., 1996). Very low dosage of 2-mercapto-5-nitro benzimidazole-stabilized Gold nanoparticles, which can release NO, exhibited appreciable tumoricidal effect against cervical cancer, demonstrating the role of NO in killing cancer cells (Sudhesh et al., 2013). Our present results indicate that NO is a regulatory factor that can down-regulate HPV early E6 expression, which may explain how NO kills cervical cancer cells.

In conclusion, for the first time we show that NO inhibits the transcription of HPV E6 gene and probably involves MAPK signaling pathway. The combination of NO and ERK inhibitors may be a powerful strategy to treat HPV associated cancers.

Acknowledgments. This work was supported by grants from the National Natural Science Foundation of China (No. 81672670 and 81672584), and the Natural Science Foundation of Heilongjiang province (jc2018023 and D201047). We thank financial support from the Heilongjiang HFPC science foundation (No. 2018-300).

\section{References}

Akaike T, Maeda H (2000): Nitric oxide and virus infection. Immunology 101, 300-308. https://doi.org/10.1046/j.13652567.2000.00142.x

Baek MW, Seong KJ, Jeong YJ, Kim GM, Park HJ, Kim SH, Chung HJ, Kim WJ, Jung JY (2015): Nitric oxide induces apoptosis in human gingival fibroblast through mitochondriadependent pathway and JNK activation. Int. Endod. J. 48, 287-297. https://doi.org/10.1111/iej.12314

Boyer SN, Wazer DE, Band V (1996): E7 protein of human papilloma virus-16 induces degradation of retinoblastoma protein through the ubiquitin-proteasome pathway. Cancer Res. 56, 4620-4624.

Branca M, Ciotti M, Santini D, Bonito LD, Benedetto A, Giorgi C, Paba P, Favalli C, Costa S, Agarossi A, Alderisio M, Syrjänen K (2004): HPV-Pathogen ISS Study Group. Activation of the ERK/MAP kinase pathway in cervical intraepithelial neoplasia is related to grade of the lesion but not to high-risk human papillomavirus, virus clearance, or prognosis in cervical cancer. Am. J. Clin. Pathol. 122, 902-911. https://doi.org/10.1309/VQXFT880JXC7QD2W

Choudhari SK, Chaudhary M, Bagde S, Gadbail AR, Joshi V (2013): Nitric oxide and cancer: a review. World J. Surg. Oncol. 11, 118. https://doi.org/10.1186/1477-7819-11-118

Demirel I, Vumma R, Mohlin C, Svensson L, Säve S, Persson K (2012): Nitric oxide activates IL-6 production and expres- sion in human renal epithelial cells. Am. J. Nephrol. 36, 524-530. https://doi.org/10.1159/000345351

Feng X, Sun T, Bei Y, Ding S, Zheng W, Lu Y, Shen P (2013): S-nitrosylation of ERK inhibits ERK phosphorylation and induces apoptosis. Sci. Rep. 3, 1814. https://doi. org/10.1038/srep01814

Gallo EF, Iadecola C (2011): Neuronal nitric oxide contributes to neuroplasticity-associated protein expression through cGMP, protein kinase $G$, and extracellular signalregulated kinase. J. Neurosci. 31, 6947-6955. https://doi. org/10.1523/JNEUROSCI.0374-11.2011

Gao X, Tajima M, Sairenji T (1999): Nitric oxide down-regulates Epstein-Barr virus reactivation in epithelial cell lines. Virology 258, 375-381. https://doi.org/10.1006/viro.1999.9748

Kielbik M, Klink M, Brzezinska M, Szulc I, Sulowska Z (2013): Nitric oxide donors: spermine/NO and diethylenetriamine/ NO induce ovarian cancer cell death and affect STAT3 and AKT signaling proteins. Nitric Oxide 35, 93-109. https:// doi.org/10.1016/j.niox.2013.09.001

Komatsu T, Sakurada S, Kohno K, Shiohira H, Katsuyama S, Sakurada C, Tsuzuki M, Sakurada T (2009): Spinal ERK activation via NO-cGMP pathway contributes to nociceptive behavior induced by morphine-3-glucuronide. Biochem. Pharmacol. 78, 1026-1034. https://doi.org/10.1016/j. bcp.2009.06.106

Miyamoto Y, Sakai R, Maeda C, Takata T, Ihara H, Tsuchiya Y, Watanabe Y (2011): Nitric oxide promotes nicotinetriggered ERK signaling via redox reactions in PC12 cells. Nitric Oxide 25, 344-349. https://doi.org/10.1016/j. niox.2011.06.006

Moncada S, Higgs A (1993): The L-arginine-nitric oxide pathway. N. Engl. J. Med. 329, 2002-2012. https://doi.org/10.1056/ NEJM199312303292706

Nott A, Riccio A (2009): Nitric oxide-mediated epigenetic mechanisms in developing neurons. Cell Cycle 8, 725-730. https://doi.org/10.4161/cc.8.5.7805

Park WH (2013): The effect of MAPK inhibitors and ROS modulators on cell growth and death of $\mathrm{H} 2 \mathrm{O} 2$-treated HeLa cells. Mol. Med. Rep. 8, 557-564. https://doi.org/10.3892/ mmr.2013.1551

Ridnour LA, Thomas DD, Donzelli S, Espey MG, Roberts DD, Wink DA, Isenberg JS (2006): The biphasic nature of nitric oxide responses in tumor biology. Antioxid. Redox Signal 8, 1329-1337. https://doi.org/10.1089/ars.2006.8.1329

Sudhesh P, Tamilarasan K, Arumugam P, Berchmans S (2013): Nitric oxide releasing photoresponsive nanohybrids as excellent therapeutic agent for cervical cancer cell lines. ACS Appl. Mater Interfaces 5, 8263-8266. https://doi. org/10.1021/am402086m

Walboomers JM, Jacobs MV, Manos MM, Bosch FX, Kummer JA, Shah KV, Snijders PJ, Peto J, Meijer CJ, Mu-oz N (1999): Human papillomavirus is a necessary cause of invasive cervical cancer worldwide. J. Pathol. 189, 12-19. https://doi. org/10.1002/(SICI)1096-9896(199909)189:1<12::AIDPATH431>3.0.CO;2-F

Xu W, Liu LZ, Loizidou M, Ahmed M, Charles IG (2002): The role of nitric oxide in cancer. Cell Res. 12, 311-320. https:// doi.org/10.1038/sj.cr.7290133 
Yasui H, Ito N, Yamamori T, Nakamura H, Okano J, Asanuma T, Nakajima T, Kuwabara M, Inanami O (2010): Induction of neurite outgrowth by alpha-phenyl-N- tert-butylnitrone through nitric oxide release and Ras-ERK pathway in PC12 cells. Free Radic. Res. 44, 645-654. https://doi. org/10.3109/10715761003692537

Yu, CF, Hong JH, Chiang CS (2013): The roles of macrophages and nitric oxide in interleukin-3-enhanced HSV-Sr39tkmediated prodrug therapy. PLoS One 8, e56508. https:// doi.org/10.1371/journal.pone.0056508
Yu JH, Lin BY, Deng W, Broker TR, Chow LT (2007): Mitogenactivated protein kinases activate the nuclear localization sequence of human papillomavirus type 11 E1 DNA helicase to promote efficient nuclear import. J. Virol. 81, 5066-5078. https://doi.org/10.1128/JVI.02480-06

Yuan H, Ito S, Senga T, Hyodo T, Kiyono T, Kikkawa F, Hamaguchi M (2009): Human papillomavirus type 16 oncoprotein E7 suppresses cadherin-mediated cell adhesion via ERK and AP-1 signaling. Int. J. Oncol. 35, 309-314. 